\title{
Discrimination of Scots pine forests in the Iberian Central System (Pinus sylvestris var. iberica) by means of pollen analysis. Phytosociological considerations
}

\author{
José Antonio López-Sáez (*), Daniel Sánchez-Mata (**), \\ Francisca Alba-Sánchez (***), Daniel Abel-Schaad (*), Rosario G. Gavilán (**) \\ \& Sebastián Pérez-Díaz (*)
}

\begin{abstract}
López-Sáez, J.A., Sánchez-Mata, D., Alba-Sánchez, F., Abel-Schaad, D., Gavilán, R.G. \& Pérez-Díaz, S. Discrimination of Scots pine forests in the Iberian Central System (Pinus sylvestris var. iberica) by means of pollen analysis. Phytosociological considerations. Lazaroa 34: 191-208 (2013).

Fifty-eight modern pollen surface samples from different Scots pine forest communities (Pinus sylvestris var. iberica Svoboda) in the Iberian Central System (central Spain) were palynologically and statistically analyzed (using hierarchical cluster analysis and principal component analysis) to derive correlations between pollen assemblages and environmental gradients at the sampled points. Numerical classification and ordination were performed on pollen data to assess similarities among (central Iberian)-Scots pine forest phytosociological associations. The results show a strong relationship between altitude, temperature, rainfall, arboreal cover and variations in pollen taxa percentages. The statistic discrimination of some of these forest communities has allowed us to propose three new associations.
\end{abstract}

Keywords: Pinus sylvestris var. iberica, Iberian Central System, Palynology, Phytosociology, Multivariate Analyses, Community Ecology.

Resumen: López-Sáez, J.A., Sánchez-Mata, D., Alba-Sánchez, F., Abel-Schaad, D., Gavilán, R.G. \& Pérez-Díaz, S. Discriminación de los bosques de pino albar en el Sistema Central ibérico (Pinus sylvestris var. iberica) mediante análisis polínico. Consideraciones fitosociológicas. Lazaroa 34: 191-208 (2013).

Cincuenta y ocho muestras de lluvia polínica actual, procedentes de distintas comunidades forestales de pino albar (Pinus sylvestris var. iberica Svoboda) en el Sistema Central ibérico (centro de España), fueron analizadas palinológica y estadísticamente (mediante análisis de cluster jerárquico y análisis de componentes principales) para establecer correlaciones entre los espectros polínicos y gradientes medioambientales. La clasificación numérica y la ordenación fueron realizadas sobre los datos polínicos para delimitar posibles similitudes entre las distintas asociaciones fitosociológicas de los bosques de pino albar centro-ibérico. Los resultados muestran que existe una fuerte correlación entre la altitud, temperatura, precipitación y cobertura arbórea respecto a las variaciones en los porcentajes de los principales morfotipos polínicos. La discriminación estadística de algunas de estas formaciones forestales nos hace proponer tres nuevas asociaciones.

Palabras clave: Pinus sylvestris var. iberica, Sistema Central ibérico, Palinología, Fitosociología, análisis multivariantes, ecología de las comunidades vegetales.

\footnotetext{
* Grupo de Investigación Arqueobiología. Instituto de Historia. CCHS. CSIC. Albasanz 26-28. E-28037 Madrid. EspañaSpain.E-mail: joseantonio.lopez@cchs.csic.es, dabel222@hotmail.com, sebas.perezdiaz@gmail.com

** Departamento de Biología Vegetal II. Facultad de Farmacia. Universidad Complutense. E-28040 Madrid. España-Spain. E-mail: dsmata@ucm.es, rgavilan@ucm.es

*** Departamento de Biología Vegetal. Facultad de Ciencias. Universidad de Granada. E-18001 Granada. España-Spain. Email: falba@ugr.es
} 


\section{INTRODUCTION}

Pollen analysis is one of the main methods used to reconstruct vegetation patterns and landscapes of the past. However, the interpretation of the composition and structure of forest communities as well as treeless vegetation from fossil pollen assemblages is complex and sometimes difficult. Pollen production and preservation, dispersal and surface deposition differ distinctively, depending on plant species and climatic conditions (Sugita, 1994; Hicks, 2001; Bunting \& al., 2004). In addition, pollen records vary with vegetation types, size of the depositional basin and other characteristics of the study area (JACOBSON $\&$ BRADSHAW, 1981). These facts are especially significant in mountainous environments, where climate varies strongly with altitude, largely determining the zonation of vegetation (RIVASMARTínEZ, 2005), reflected in turn by the pollen record at different elevations (CASELDINE \& PARdoe, 1994; Pardoe, 2001; Cañellas-Boltà \& al., 2009).

To date few studies of modern pollen rain have been attempted on mountain environments in central Spain (VÁZQUEZ \& PEINADO, 1993; ANDRADE \& al., 1994; DORADO \& RUIZ-ZAPATA, 1994). However, these investigations were generally quite local in extent and tended to include only a limited number of samples. Thus any ecological interpretation of their findings had to be confined to the local scale. Consequently, whilst pollen-based reconstructions of Holocene vegetation and climate yield good results when applied to pollen sequences from low to mid elevation sites (CARRIÓN \& al., 2010; GIL-RoMERA \& al., 2010), the application of current methods to high-altitude pollen sequences often gives unreliable or hardly testable results. Ultimately, analyses of modern pollen rain are essential for the understanding of fossil pollen sequences in a particular mountain area, and therefore for pollen-based palaeovegetation and palaeoclimate reconstructions (LÓPEZ-SÁEZ \& al., 2010a). This is particularly marked in the case of large pollen producers and wind-pollinated taxa like pine species. In this sense, CASELDINE \& al. (2007) stressed the importance of making realistic assumptions about regional background pollen, especially about high pollen producers, such as Pinus sylvestris s. 1., in order to obtain reliable simulations in landscape modelling.

Pinus species cover large areas of the Northern Hemisphere and their forests have an ancient history of human impact that has shaped their current structure, composition and distribution (RICHARDSON \& al., 2007). In the Mediterranean Basin, the distribution of pines, especially the most abundant and widespread one such as Pinus sylvestris s. 1., has been greatly affected by human activities for thousands of years (BARBERO \& al., 1998; TAPIAS \& al., 2004). The human role in structuring Scots pine forests in the Iberian Central System shows how they have declined considerably as a result of livestock and agriculture activities, land abandonment, forestry, and extensive afforestation (MARTínEZGarcía \& MONTERO, 2000), especially in the last five thousand years (FRANCO-MúGICA \& al., 2001a). The fact that wildfires in the Iberian Central System have mostly affected Pinus sylvestris var. iberica Sbovoda forests located in dry and subhumid areas implies that climate contributes to limit fire occurrence (PAUSAS \& al., 2008) and, therefore, changes in future climate will be likely to modify the fire regime, and, consequently, the vulnerability to fire of Scots pine forests in the study area.

Here, we study for the first time modern pollen samples from the Iberian Central System to discriminate Pinus sylvestris var. iberica forest communities, as modern pollen studies can aid in the interpretation of fossil pollen data in terms of vegetation patterns. Pinus sylvestris s. 1. is a widespread species in Europe (MASON \& ALÍA, 2000) that has left a useful record of its distribution in central Spain during the Holocene in the form of pollen grains and macrofossils preserved in sediments (FrANCO-MÚGICA \& al., 2001; RUBIALES \& al., 2007, 2012; LÓPEZ-MERINO \& al., 2009). Furthermore, these studies may help to disentangle the factors that triggered vegetation changes. This analysis aims to serve as a basis for further historical reconstruction of vegetation changes during the Holocene in high-mountain environments based on fossil pollen data. 


\section{MATERIAL AND METHODS}

\section{POLLEN DATA}

Fifty-eight modern pollen surface samples (moss polsters) were collected in natural Pinus sylvestris var. iberica forests from the Iberian Central System (Figure 1), with positional and altitudinal data recorded using a portable Garmin Ltd. Global Positioning System (GPS) device. Moss samples were collected over an area of approximately $100 \mathrm{~m}^{2}$ by taking multiple moss polsters from the concerned site to ensure an even representation (GAILLARD \& al., 1992, 1994). The subsamples were sealed in plastic bags and mixed into one sample per site. Moss polsters are commonly used as surface samples for local modern pollen rain as it is assumed that they record an average of several years of pollen deposition and are a good analogue of fossil pollen assemblages.

Table 1 list the locations and gives a short description about each recorded site in the study region. A relevé of vegetation was made at each sampling site.

Palynomorphs were extracted from the moss samples following the standard protocol developed by FAEGRI \& IVERSEN (1989) and mounted on microscope slides in water-free glycerol. Pollen grains and non-pollen palynomorphs were identified according to MOORE \& al. (1991), RAMIL \& al. (1992) and LÓPEZ-SÁEZ \& LÓPEZ-MERINO (2007) at the lowest currently possible taxonomical level. Ononis type was palynologically identified by its grain larger than $27 \mu \mathrm{m}$ and its visible columellae (under phase contrast); and Viscum album according to LÓPEZ-SÁEZ (1999). Unfortunately it was impossible to differentiate pollen morphology of Genisteae species or genera (PRADOS \& al., 1985).

A Nikon Eclipse 50i light-microscope (Melville, NY, U.S.A.) was used to identify and count pollen. Routine counting was carried out at $400 x$ magnification. A minimum of 500 pollen grains were counted from each sample. Pollen percentages were calculated using a pollen sum excluding spores and hydro-hygrophytes, and presented as bars in a pollen percentage diagram. Tilia and TGView (GRIMM, 1992) and CorelDraw software were used to plot the pollen diagram (Figure 2).

\section{ENVIRONMENTAL DATA}

Twelve land-use and environmental variables were available for 58 sites (Table 1). Arboreal cover was graded on an ordinal scale from 0 to 5 as follows: $5(75-100 \%), 4(50-75 \%), 3(25-$

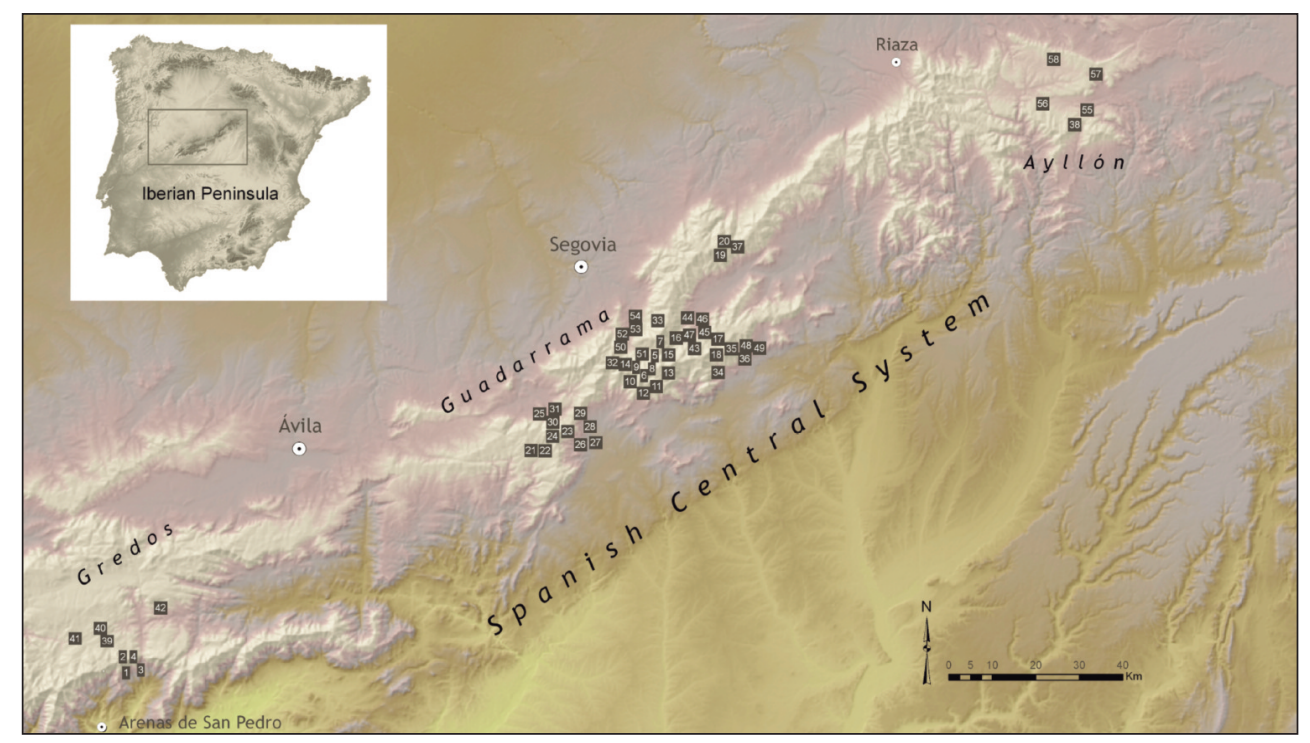

Figure 1. - Map showing the surface pollen samples in the Iberian Central System. 


\section{Table 1}

Study sites and site characteristics for the 58 modern pollen surface samples from the Iberian Central System.

Parameters: Tm: minimum temperature in the coldest month, TM: maximum temperature in the hottest month,

TA: annual temperature, Pm: precipitation in the driest month, PM: precipitation in the wettest month,

PA: annual precipitation.

\begin{tabular}{|c|c|c|c|c|c|c|c|c|c|c|c|}
\hline Sample & UTM X & $\begin{array}{c}\text { UTM Y } \\
(\mathrm{m})\end{array}$ & $\begin{array}{c}\text { Altitude } \\
\text { Cover }\end{array}$ & $\begin{array}{l}\text { Canopy } \\
\text { pressure }\end{array}$ & Grazing & $\mathrm{Tm}$ & TM & TA & $\mathrm{Pm}$ & PM & PA \\
\hline 1 & 327709 & 4464812 & 1770 & 4 & 0 & $-0,1$ & 19,8 & 8,3 & 21,9 & 171,6 & 1205 \\
\hline 2 & 327848 & 4464725 & 1715 & 4 & 0 & 0,6 & 20,1 & 8,8 & 21 & 173,6 & 1211 \\
\hline 3 & 327867 & 4464350 & 1590 & 3 & 0 & 1,3 & 20,6 & 9,5 & 20,5 & 175,9 & 1220 \\
\hline 4 & 326597 & 4464082 & 1635 & 1 & 1 & 0,7 & 20,1 & 8,8 & 19,1 & 174 & 1214 \\
\hline 5 & 416931 & 4517116 & 1800 & 5 & 0 & $-1,5$ & 17,1 & 6,5 & 33,8 & 155,1 & 1207 \\
\hline 6 & 416672 & 4516225 & 1880 & 5 & 1 & $-2,3$ & 16,6 & 6 & 38,2 & 165,3 & 1303 \\
\hline 7 & 418093 & 4519516 & 1780 & 5 & 0 & $-0,1$ & 18,2 & 7,6 & 27,6 & 138 & 1049 \\
\hline 8 & 416618 & 4516525 & 1816 & 5 & 0 & $-1,8$ & 16,9 & 6,3 & 38,6 & 166,5 & 1308 \\
\hline 9 & 413883 & 4515273 & 1888 & 5 & 0 & $-2,6$ & 15,7 & 5,3 & 33,1 & 183,5 & 1381 \\
\hline 10 & 415407 & 4515938 & 1860 & 5 & 0 & $-1,7$ & 16,2 & 5,9 & 30,7 & 177,7 & 1330 \\
\hline 11 & 415337 & 4514482 & 1750 & 5 & 0 & $-1,3$ & 16,4 & 6,3 & 31,4 & 186,5 & 1380 \\
\hline 12 & 414783 & 4513166 & 1650 & 4 & 0 & $-0,3$ & 17,7 & 7,6 & 30,5 & 174,2 & 1273 \\
\hline 13 & 419149 & 4519056 & 1830 & 5 & 0 & $-1,1$ & 17,7 & 6,9 & 27,1 & 133 & 1018 \\
\hline 14 & 416604 & 4516342 & 1874 & 5 & 0 & $-2,3$ & 16,6 & 6 & 38,2 & 165,3 & 1303 \\
\hline 15 & 419040 & 4519753 & 1840 & 4 & 0 & -1 & 17,7 & 7 & 25,4 & 132 & 1001 \\
\hline 16 & 420360 & 4520139 & 1700 & 5 & 0 & $-0,4$ & 18,1 & 7,5 & 23,9 & 126,5 & 957 \\
\hline 17 & 429870 & 4519977 & 1785 & 5 & 0 & $-0,8$ & 18,5 & 7,6 & 27,4 & 106,8 & 862 \\
\hline 18 & 430590 & 4519855 & 1632 & 5 & 0 & -1 & 18,5 & 7,6 & 29,4 & 106,2 & 876 \\
\hline 19 & 431758 & 4537645 & 1816 & 5 & 0 & $-0,1$ & 18,5 & 7,8 & 23,4 & 91,2 & 732 \\
\hline 20 & 430462 & 4537131 & 1921 & 1 & 0 & $-0,4$ & 18 & 7,2 & 22,4 & 95,3 & 751 \\
\hline 21 & 398281 & 4500981 & 1458 & 4 & 3 & 1,3 & 19,9 & 9,2 & 19,8 & 107,2 & 794 \\
\hline 22 & 397621 & 4500359 & 1473 & 5 & 2 & 1,7 & 20,1 & 9,6 & 19,3 & 107,3 & 789 \\
\hline 23 & 402525 & 4506945 & 1425 & 4 & 0 & 1,4 & 19,4 & 9,1 & 23,7 & 112,5 & 851 \\
\hline 24 & 402768 & 4506096 & 1572 & 5 & 0 & 1 & 19,3 & 8,9 & 25,2 & 118,4 & 885 \\
\hline 25 & 399226 & 4506837 & 1350 & 5 & 0 & 1,9 & 19,3 & 9,4 & 27,5 & 103 & 815 \\
\hline 26 & 403764 & 4502750 & 1510 & 5 & 0 & 2,7 & 20,9 & 10,6 & 19 & 130 & 860 \\
\hline 27 & 404179 & 4505126 & 1400 & 5 & 0 & 2,2 & 20,1 & 9,7 & 17,8 & 125,2 & 852 \\
\hline 28 & 405427 & 4504572 & 1350 & 4 & 0 & 2,7 & 20,9 & 10,6 & 18,5 & 128,3 & 859 \\
\hline 29 & 402585 & 4506997 & 1487 & 5 & 0 & 1,4 & 19,4 & 9,1 & 23,7 & 112,5 & 851 \\
\hline 30 & 401615 & 4506304 & 1425 & 4 & 0 & 1,5 & 19,3 & 9,1 & 25,6 & 112,2 & 859 \\
\hline 31 & 399328 & 4507690 & 1350 & 5 & 0 & 2,8 & 19,7 & 9,8 & 20,9 & 99,9 & 743 \\
\hline 32 & 414113 & 4517053 & 1692 & 5 & 0 & $-0,4$ & 17,4 & 7,3 & 31,4 & 166,9 & 1253 \\
\hline 33 & 417166 & 4523212 & 1725 & 4 & 0 & $-0,2$ & 18,6 & 8 & 29,6 & 116,4 & 946 \\
\hline 34 & 431401 & 4519460 & 1533 & 5 & 0 & $-0,1$ & 19,3 & 8,6 & 31,9 & 104,8 & 883 \\
\hline 35 & 432348 & 4518261 & 1457 & 5 & 0 & 1,2 & 19,7 & 9,2 & 21,6 & 100,8 & 778 \\
\hline 36 & 432267 & 4516523 & 1305 & 5 & 0 & 2,9 & 20,6 & 10,7 & 18,3 & 99,6 & 735 \\
\hline 37 & 431047 & 4536158 & 1654 & 4 & 0 & 0,8 & 19 & 8,4 & 21,3 & 92,2 & 726 \\
\hline 38 & 489594 & 4557566 & 1800 & 4 & 0 & $-0,9$ & 17,2 & 6,7 & 20,6 & 80,9 & 645 \\
\hline 39 & 321560 & 4468930 & 1572 & 5 & 0 & 1,2 & 20,6 & 9,5 & 18,7 & 144,5 & 1006 \\
\hline 40 & 320378 & 4469216 & 1575 & 4 & 0 & 1,3 & 20,5 & 9,6 & 18 & 139,3 & 966 \\
\hline 41 & 316024 & 4467375 & 1465 & 4 & 0 & 1,6 & 21 & 10,1 & 21,1 & 138,3 & 967 \\
\hline 42 & 330826 & 4472781 & 1340 & 5 & 1 & 1,8 & 21,1 & 10,2 & 17,4 & 141,1 & 986 \\
\hline 43 & 423550 & 4520940 & 1400 & 5 & 0 & 1,7 & 19,5 & 9,5 & 25,9 & 119,5 & 917 \\
\hline 44 & 424949 & 4521863 & 1320 & 5 & 0 & 1,9 & 19,3 & 9,5 & 23,8 & 113,4 & 868 \\
\hline 45 & 425284 & 4522320 & 1300 & 4 & 0 & 2,3 & 19,5 & 9,9 & 24,7 & 113 & 870 \\
\hline 46 & 424945 & 4523467 & 1325 & 5 & 1 & 2,2 & 19,2 & 9,8 & 23,2 & 109,4 & 843 \\
\hline
\end{tabular}




\begin{tabular}{cccccccccccc} 
Sample & UTM X & $\begin{array}{c}\text { UTM Y } \\
(\mathrm{m})\end{array}$ & $\begin{array}{c}\text { Altitude } \\
\text { Cover }\end{array}$ & $\begin{array}{c}\text { Canopy } \\
\text { pressure }\end{array}$ & Grazing & Tm & TM & TA & Pm & PM & PA \\
\hline 47 & 422678 & 4520646 & 1500 & 5 & 0 & 1,2 & 19,2 & 9 & 25,8 & 120,1 & 922 \\
48 & 434957 & 4518806 & 1305 & 5 & 1 & 2,9 & 20,8 & 10,7 & 16,4 & 94,6 & 695 \\
49 & 434826 & 4518377 & 1215 & 4 & 1 & 3,2 & 21,1 & 11 & 17 & 94,9 & 700 \\
50 & 413441 & 4520519 & 1320 & 5 & 1 & 1,7 & 19,6 & 9,6 & 24,9 & 129,6 & 975 \\
51 & 415464 & 4518224 & 1564 & 5 & 1 & $-0,2$ & 18,1 & 7,9 & 31,1 & 148,6 & 1141 \\
52 & 413445 & 4520865 & 1293 & 5 & 1 & 1,8 & 19,8 & 9,7 & 24,4 & 126,6 & 955 \\
53 & 413321 & 4522269 & 1254 & 5 & 1 & 2 & 20,1 & 10 & 26,1 & 118,6 & 917 \\
54 & 413264 & 4523988 & 1215 & 5 & 2 & 2,4 & 20,5 & 10,4 & 23,1 & 108 & 836 \\
55 & 491756 & 4560145 & 1685 & 3 & 0 & $-0,1$ & 17,6 & 7,7 & 25,5 & 82,6 & 663 \\
56 & 484031 & 4561244 & 1520 & 4 & 0 & 0,1 & 18,1 & 7,9 & 24,5 & 82,9 & 685 \\
57 & 493275 & 4566455 & 1445 & 3 & 0 & 0,1 & 18,2 & 8,1 & 25,5 & 78,4 & 627 \\
58 & 485912 & 4569044 & 1370 & 3 & 1 & 0,7 & 18,9 & 8,6 & 24,2 & 76,5 & 636 \\
\hline
\end{tabular}

$50 \%), 2(5-25 \%), 1(1-5 \%), 0(0 \%)$. In situ observation and the Forest Map of Spain (1:200.000) (RUIZ DE LA TORRE, 2002) were the tools used for estimating the current vegetation cover. Grazing pressure was calculated taking a 0 to 4 index into account (COURT-PICON \& al., 2006). The climatic information was taken from the Digital Climatic Atlas of the Iberian Peninsula (NINYEROLA \& al., 2006, 2007; Pons \& NinYerola, 2007). Bioclimatical concepts and nomenclature follow the recent published proposals of RIVAS-MARTínEZ \& al. $(2007,2011 b)$. The topographic data came from the Shuttle Radar Topography Mission (FARR \& al., 2007), resampled from $90 \mathrm{~m}$ to 200 m [(5810 x 4600 cells, Universal Transverse Mer- cator (UTM) projection, European datum 1950 (ED50)].

\section{Classification}

To identify clusters of samples based on their pollen content and hence to define specific Pinus sylvestris var. iberica forest communities, we used multivariate analysis. Although 87 pollen and spore taxa were identified in the surface samples, only palynomorph taxa present at $>1 \%$ were included (44). The analyses were performed on recalculated percentages after all modifications had been made. Hierarchical cluster analysis (HCA) was performed using the matrix of the eu-

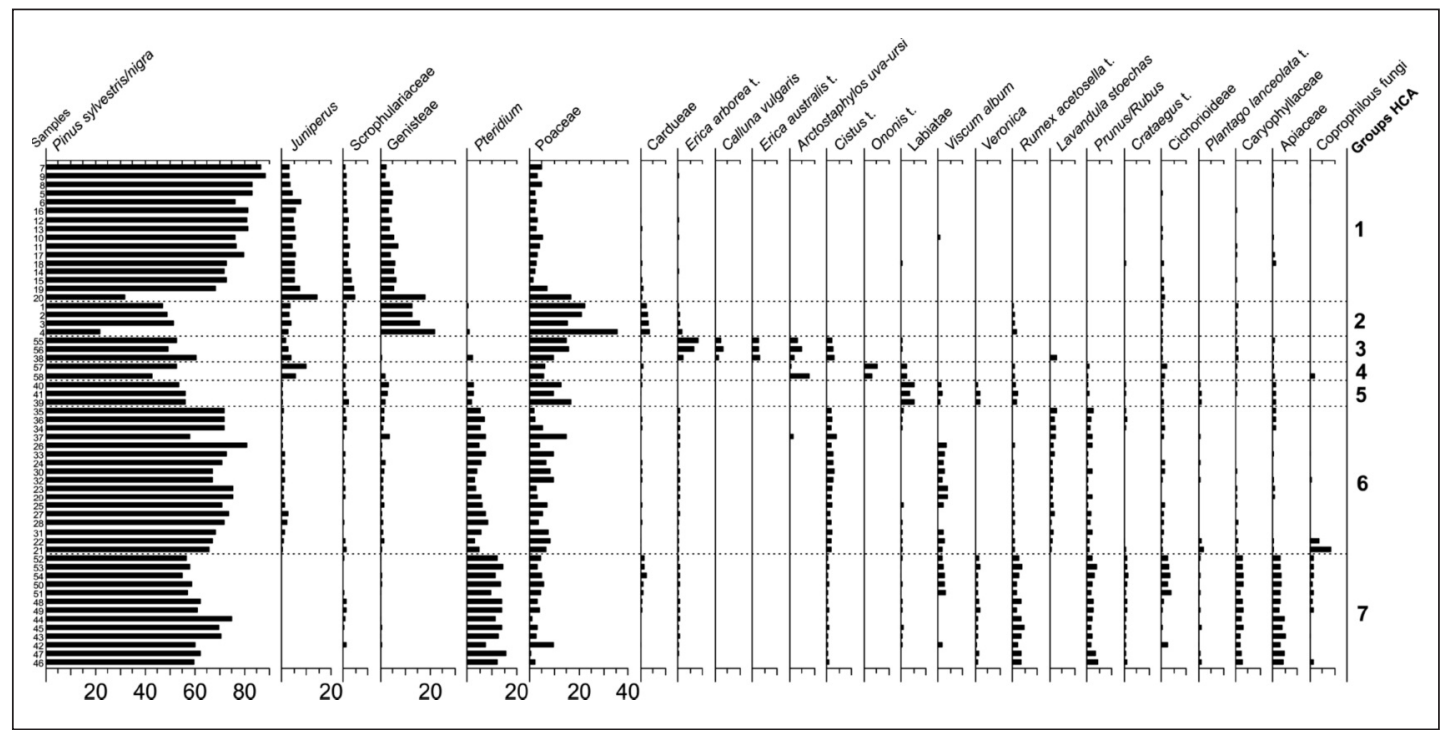

Figure 1. - Percentage pollen diagram for selected taxa. 
clidean distances and Ward's minimum variance method (WARD, 1963) with the program IBM SPSS Statistics 21. The percentage values of each taxa were standardized. The hierarchical relationships between clusters are illustrated by the dendrogram in Figure 3.

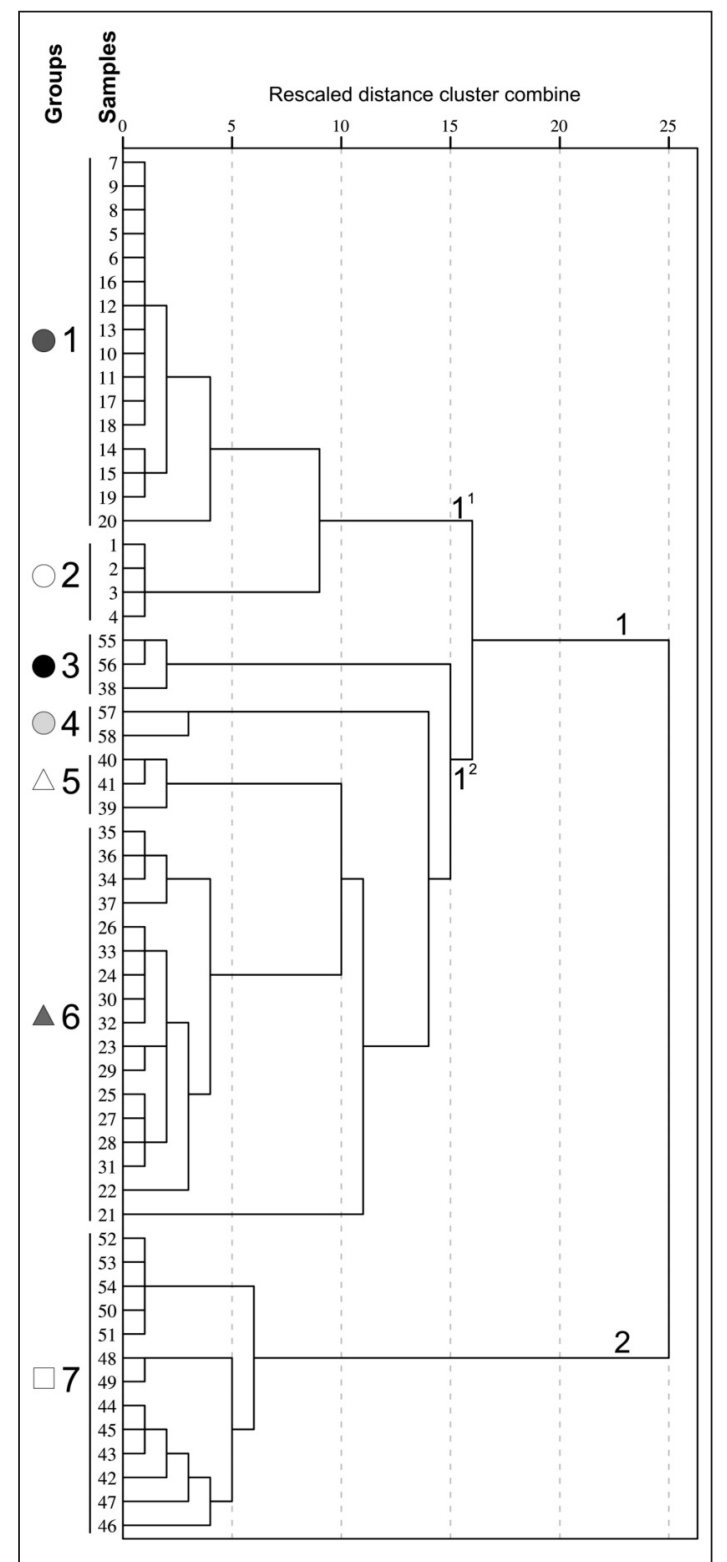

Figure 3. - Hierarchical cluster analysis (HCA) of the 58 modern pollen spectra from Pinus sylvestris var. iberica forest communities in the Iberian Central System. Dotted lines indicate the different thresholds that subdivides the dendrogram mentioned in the text, from right to left.

\section{ORDINATIONS}

Data were processed (modern surface pollen samples) by ordination analysis to obtain more information about the data structure. Principal component analysis (PCA) was used as a linear interpretation method because a previously applied detrended canonical correspondence analysis (DCCA) pointing to a linear response of pollen types (variables) to environmental gradients (EsCUDERO \& al., 1994; BIRKS \& al., 1998). PCA is an indirect ordination procedure that reduces the multidimensional nature of a data set to a few dimensions (defined by principal components), with minimal loss of information. PCA was used to study the dominant features of the data set in terms of variance. Samples were square-root transformed for a better comparability (AUSTIN, 2013). PCA analysis was carried out on the correlation matrix of the pollen data; principal component scores of the pollen spectra (samples) and loadings for the variables (pollen types) were positioned on the main principal components in a biplot (Figures 4 and 5).

To extract more information from the modern pollen record, supplementary environmental gradients in the ordination project were included (Table 1). These gradients were gained from the interpolated climatic information from the Iberian Peninsula or from our own observation on human impact. We included TA (annual temperature), TM (maximum temperature in the hottest month), Tm (minimum temperature in the coldest month), PA (annual precipitation), PM (precipitation in the wettest month), $\mathrm{Pm}$ (precipitation in the driest month) and the measure of human activity (grazing) as passive (supplementary) environmental gradients. Partial redundancy analysis (RDA) was conducted to see which environmental gradient explains better the dataset (Table 2).

The analyses were run using the $\mathrm{C} 21.5$ software (JuGGINS, 2007). Graphics of the ordination biplots were achieved by using CorelDraw. Analyses were processed with palynomorph taxa present at $>1 \%$.

\section{NOMENCLATURE}

Taxonomic nomenclature and authorities follow the published volumes of Flora iberica (CASTROVIEJO 


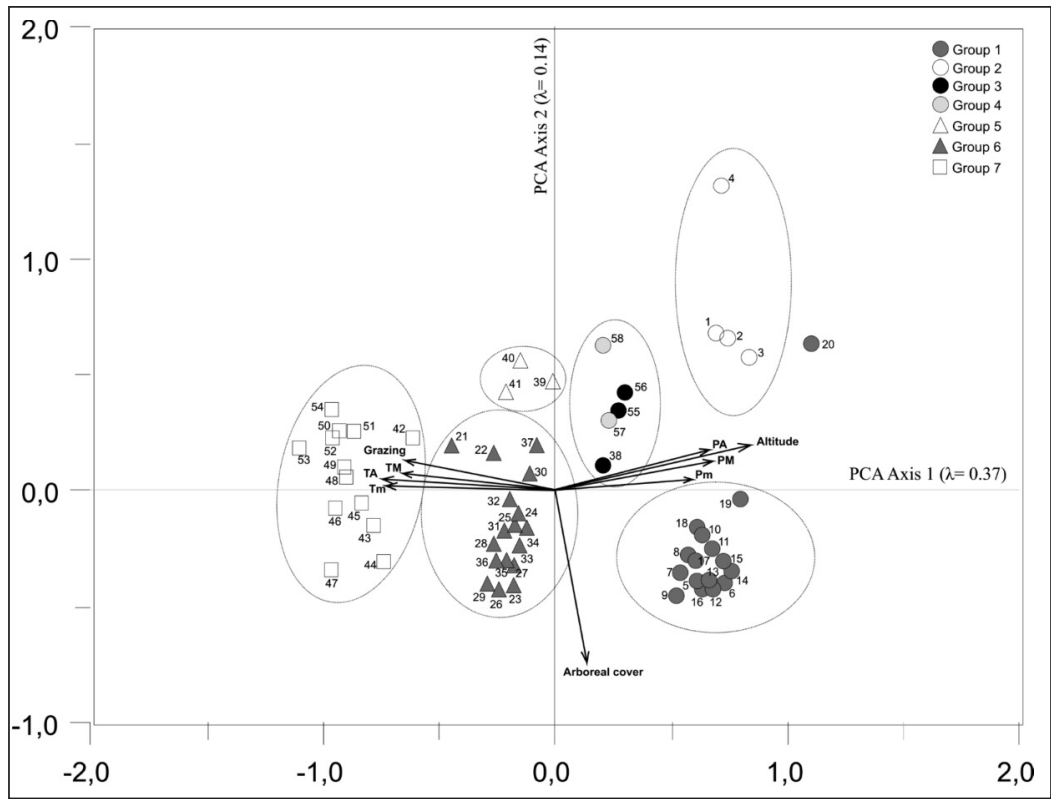

Figure 4. - PCA plot for the surface samples showing ordination of samples along the first and second PCA axis. Significance of analysis can be comprehended in Table 2. Main characteristics for the theoretical gradients are obtained from the correlation of supplied environmental gradients. Each sample is expressed by the observed vegetation types (see Figure 3).

\& al., 1986-2012) and the compilations of Flora Eu- Syntaxonomical scheme, nomenclature, and syntaxa ropaea (TuTin \& al., 1964-1980); the exceptions are authorities follow the compilations and proposals of specifically mentioned in the floristic appendix. RIVAS-MARTínEZ \& al. (2001, 2002, 2011a).

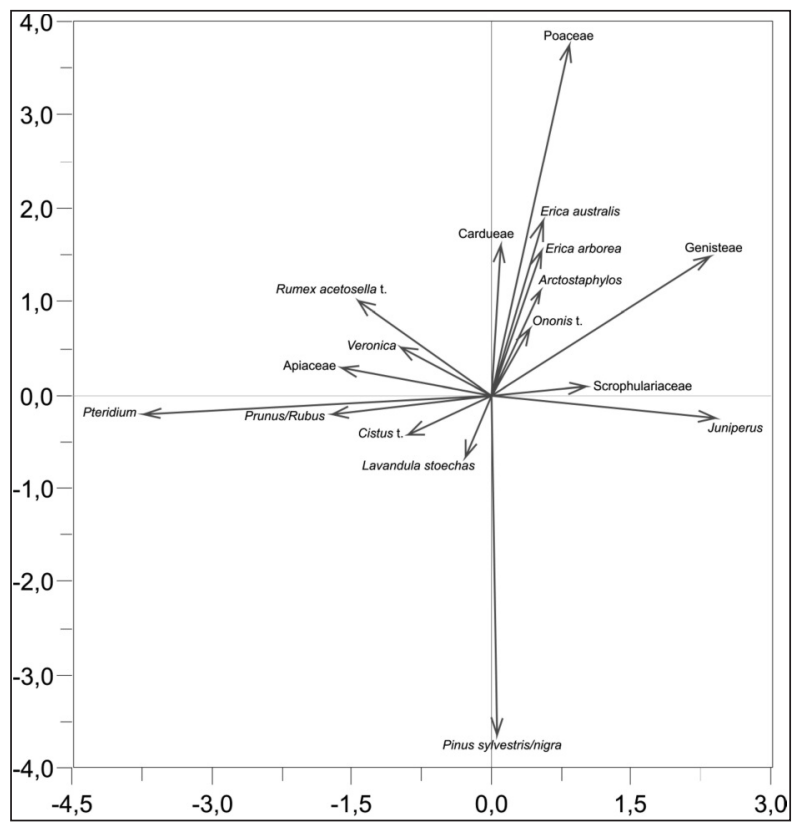

Figure 5. - PCA plot for the pollen types (variables) along the first and second PCA axis. Taxa positioned near the origin are not displayed. 
Table 2

Results of partial RDA and PCA for pollen data of surface samples

All gradients are significant at the 5\% significance level $(p \leq 0.05)$

\begin{tabular}{lcccc}
\hline Gradient & Explained variance & p-value & $\begin{array}{c}\text { Correlation with PCA-1 } \\
(\lambda=0.37)\end{array}$ & $\begin{array}{c}\text { Correlation with PCA-2 } \\
(\lambda=0.14)\end{array}$ \\
\hline Altitude & $17 \%$ & 0.002 & 0.80 & 0.33 \\
Canopy cover & $10 \%$ & 0.005 & 0.12 & -0.75 \\
Grazing & $3 \%$ & 0.01 & -0.62 & 0.19 \\
TA & $14 \%$ & 0.002 & -0.80 & 0.05 \\
TM & $11 \%$ & 0.005 & -0.64 & 0.09 \\
Tm & $8 \%$ & 0.005 & -0.75 & 0.02 \\
PA & $15 \%$ & 0.002 & 0.66 & 0.17 \\
PM & $12 \%$ & 0.002 & 0.69 & 0.12 \\
Pm & $9 \%$ & 0.005 & 0.61 & 0.05 \\
\hline
\end{tabular}

\section{RESULTS AND DISCUSSION}

The pollen and non-pollen palynomorph percentage data for selected taxa are presented in Figure 2. Pinus sylvestris/nigra type pollen percentage in surface samples range from $22 \%$ to $89 \%$. It is clearly evident from the results that Pinus sylvestris has, due to high pollen production and good dispersal ability, a larger pollen dispersal area that the other studied species (POSKA \& PIDEK, 2010). In the study region Pinus nigra could also contribute to the total Pinus sylvestris/nigra type pollen deposition but it is likely of minor importance in comparison to the one of $P$. sylvestris.

On the first division level, the dendrogram of the HCA performed on pollen data (Figure 3) shows a clear discrimination between xerophilous Pinus sylvestris var. iberica forest communities (cluster 1; groups 1 to 6) and mesophilous ones (cluster 2; group 7). The following threshold of cluster 1 clearly separates samples from centralwestern orotemperate submediterranean (orosubmediterranean) communities (cluster $1^{1}$ ) from those of the eastern supratemperate (suprasubmediterranean) and supramediterranean belts (cluster $\left.1^{1}\right)$. The division of cluster $1^{1}$ provides two groups ( 1 and 2 ) while cluster 12 is divided into four groups (3 to 6).

Groups 1 and 2 represent xerophilous and orophilous ( $>1600 \mathrm{~m}$ ) forest communities from the orosubmediterranean belt of the Guadarrama and the Gredos ranges respectively (Table 1). Although the average annual precipitation (PA) va- lues are high (usually $>1200 \mathrm{~m}$ ), these forests are considered as xerophilous because they are covered by winter snow for at least 4-5 months and grow on moderate to highly stony soils with low edaphic development (GAVILÁN \& al., 1998; Martínez-García \& Montero, 2000; GaVILÁN, 2005; LóPEZ-LEIVA \& al., 2009). They are characterized by noticeable percentages of Pinus sylvestris (> 20\%) and significant frequencies of Poaceae, Genisteae and Juniperus (Figure 2). They are individualized by (i) higher Pinus sylvestris (68-89\%) and Juniperus (3-8\%) values in group 1 and lower ones in group 2 (22-51\% and 2-4\% respectively), (ii) lower percentages of Poaceae (3-7\%), Cardueae $(<1 \%)$ and Genisteae (3-7\%) in group 1 and relatively high values in group $2(16-36 \%, 2-4 \%$ and $13-22 \%)$, (iii) the presence of Pteridium $(<1 \%)$ and Rumex acetosella s. l. only in group 2 while Cyperaceae, Apiaceae and Fabaceae undiff. are only present in group 1.

The first two axes of the PCA biplot (Figure 4, Table 2) explain $51 \%$ of variance in the pollen surface dataset. On the first axis (PCA-1) orosubmediterranean silicicolous Pinus sylvestris var. iberica forest communities (groups 1 to 4) are also separated from supratemperate submediterranean (suprasubmediterranean) and supramediterranean ones (groups 5 to 7). The PCA-1 explains 37\% of the variance in the dataset and is positively correlated with altitude $(r: 0.80), \mathrm{PA}(r: 0.66), \mathrm{PM}(r$ : $0.69)$ and $\mathrm{Pm}(r: 0.61)$ and negatively with TA $(r$ : $-0.80)$, TM $(r:-0.64)$ and Tm $(r:-0.75)$. On the 
first PCA axis (PCA-1) orophilous shrub vegetation (Genisteae, Juniperus) are separated from low-elevation mesophilous taxa (Pteridium, Prunus/Rubus, Cistus type, Veronica, Apiaceae, Rumex acetosella s. 1.) located at the negative side of the axis (Figure 5). On the second PCA axis (PCA-2) pollen taxa from tree species (Pinus sylvestris/nigra) are located on the negative side with very high values, while high-mountain meadows (Poaceae) and shrubs (Genisteae, Erica australis s. 1., E. arborea, Arctostaphylos uva-ursi, Ononis) are located on the positive side of the PCA-2. The axis explains $14 \%$ of the variance in the dataset and is most highly negative correlated with arboreal cover $(r:-0.75)$ (Figure 4, Table 2).

A combined modern distribution range of Pinus sylvestris s.l. with gridded annual precipitation and January temperature (NEW \& al., 1999) shows that its modern range in Europe lies between 400 and $1500 \mathrm{~mm}$ year- ${ }^{-1}$ and $-18^{\circ} \mathrm{C}$ to $+8^{\circ} \mathrm{C}$ respectively. These values are reflected in the populations of central Spain (Table 1). In fact, Pinus sylvestris s.l. has a wider climatic range that the broadleaved deciduous trees in terms of both temperature and precipitation, and their natural populations may inhabit climates that are suboptimal for their growth and development (REHFELDT \& al., 2002; GAVILÁN, 2005). In short, the PCA plot underscores the importance of thermotype (bioclimatic belts) for the arrangement of Pinus sylvestris var. iberica forest communities in the Iberian Central System. PCA-1 separates orosubmediterranean communities $\left(\mathrm{Tm} \leq 0^{\circ} \mathrm{C}\right.$, TA $<9^{\circ} \mathrm{C}$, groups 1 to 4) from suprasubmediterranean and supramediterranean ones $\left(\mathrm{Tm} \geq 1^{\circ} \mathrm{C}, \mathrm{TA}>9^{\circ} \mathrm{C}\right.$, groups 5 to 7) (Table 1).

Group 1 (samples 5 to 20) represents orotemperate submediterranean (orosubmediterranean) humid and hyperhumid Pinus sylvestris var. iberica microforests (mesoforests on deep soils at lower altitudes) from the Guadarrama and surrounding mountains, corresponding to the Avenello ibericae-Pinetum ibericae association (RIVAS-MARTíneZ \& al., 2001, 2002). They grow between 1,632-1,921 m asl (Table 1) in siliceous soils in the Guadarrama Range (Navacerrada, Canencia and Navafría mountain passes, Figure 1). Although most samples from group 1 are well grouped, some of the pollen assemblages were difficult to interpret in the corresponding vegetation type. This is the case of sample 20, which on the PCA-2 is separated from the remaining samples from group 1, but grouping close with those of group 2 (Figure 4). This is due to its low arboreal cover (1). Samples from group 2 have an arboreal cover of 3 or 4 , except sample 4 with only 1 (Table 1 ), but these pine forests from the Gredos Range correspond to small and isolated nuclei or scattered trees. Instead, pine forests communities from the Guadarrama Range are very dense and extensive. This may suggest that the second axis of the PCA (PCA-2) reflects not only the tree cover but rather forest density in a regional sense.

As a result of multivariate analyses (HCA and PCA), orosubmediterranean Pinus sylvestris var. iberica forest communities from the Gredos Range (group 2, samples 1 to 4) are very well discriminated from other pine forests of the Iberian Central System (Figures 3 and 4). This fact allows us to propose a new pinewood association: Echinosparto barnadesii-Pinetum ibericae SánchezMata, Gavilán \& López-Sáez ass. nova hoc loco (Table 3, holotypus, rel. 1). It represents orotemperate submediterranean (orosubmediterranean) hyperhumid relict mesoforests growing on ranker soils at an altitudinal level ranging from 1,635 to $1,770 \mathrm{~m}$ asl throughout Gredos Mountains (Carpetan-Leonese biogeographical subprovince, Iberian Western Mediterranean province, Western Mediterranean subregion, Mediterranean region (RIVAS-MARTíneZ \& al., 2007; Figure 1, Table 1). Floristically and biogeographically it is differentiated from the eastern above mentioned Avenello ibericae-Pinetum ibericae, from the Guadarrama and surrounding ranges, by the presence of western endemic elements such as Echinospartum barnadesii subsp. barnadesii and Festuca elegans subsp. merinoi (SÁNCHEZ-MATA, 1989, 1999; DE LA FUENTE \& ORTÚÑEZ, 2001) and the absence of essentially eastern species such as Juniperus communis subsp. hemisphaerica and Festuca braunblanquetii (RIVAS-MARTíneZ \& al., 2001, 2002). So far we have only been able to inventory these forests in the surrounding summits of Puerto del Pico Pass, as in the rest of the Gredos Range only 
Table 3

Echinosparto barnadesii-Pinetum ibericae Sánchez-Mata, Gavilán \& López-Sáez ass. nova (1-4)

Festuco merinoi-Pinetum ibericae Sánchez-Mata, Gavilán \& López-Sáez ass. nova (5-8)

(Avenello ibericae-Pinion ibericae, Junipero sabinae-Pinetalia sylvestris, Junipero sabinae-Pinetea sylvestris)

\begin{tabular}{lcccccccc}
\hline Altitude $(1=10 \mathrm{~m})$ & 177 & 180 & 175 & 171 & 150 & 153 & 146 & 157 \\
Number of species & 15 & 15 & 17 & 20 & 23 & 27 & 30 & 34 \\
Relevé number & 1 & 2 & 3 & 4 & 5 & 6 & 7 & 8 \\
\hline
\end{tabular}

Characteristics

Pinus sylvestris var. iberica

Cytisus oromediterraneus

Avenella iberica

Festuca elegans subsp. merinoi

Genista cinerascens

Echinospartum barnadesii

Juniperus communis subsp. alpina

Shrubby, forest and perennials companions

Festuca gredensis

Luzula lactea

Erica arborea

Pteridium aquilinum

Poa bulbosa

Agrostis castellana

Cytisus scoparius

Genista florida

Santolina oblongifolia

Cytisus striatus subsp. eriocarpus

Festuca paniculata subsp. multispiculata

Others

Arrhenatherum elatius s. 1.

Cerastium ramosissimum

Rumex acetosella

Carduus carpetanus

Leucanthemopsis pallida subsp. alpina

Armeria caespitosa

Hieracium castellanum

Achillea millefolium

Silene nutans

Hypochoeris radicata

Spergula morisonii

Jasione montana subsp. echinata

Lotus corniculatus s. 1.

Anthoxanthum odoratum

Arenaria montana

Conopodium pyrenaeum

Viola riviniana

Ornithogalum concinnum

$\begin{array}{llllllll}5 & 4 & 4 & 4 & 5 & 4 & 4 & 4 \\ 1 & 2 & 1 & 1 & 1 & 1 & + & 1 \\ 1 & 2 & + & + & 1 & 1 & 1 & + \\ . & . & + & + & 2 & 2 & 2 & 2 \\ . & . & . & . & 1 & 2 & 2 & 2 \\ 2 & 3 & 3 & 4 & . & . & . & . \\ 1 & + & 1 & 2 & . & . & . & .\end{array}$

Other species: shrubby, forest and perennials companions: Sorbus aucuparia + in 4 and Ilex aquifolium + in 7 . Others: Thymus mastichina and Nardus stricta + in 1; Jasione sessiliflora and Urtica dioica + in 4; Senecio adonidifolius and Tanacetum corymbosum + in 7; Arenaria querioides, Hieracium murorum and Centaurea amblensis + in 8 .

Localities: Ávila, Gredos Range. 1-4: Surrounding summits of Puerto del Pico, La Rubia, Hoyos del Espino and Navarredonda de Gredos, holotypus Echinosparto-Pinetum rel. 1; 5,6,8: Navarredonda de Gredos mountain summits, holotypus Festuco-Pinetum rel. 5; 7: Hoyos del Espino summits. 
isolated and scattered trees remain today (GÉNOCVA \& al., 1992; LÓPEZ-SÁEZ \& LÓPEZ-GARCÍA, 1994; LÓPEZ-LEIVA \& al., 2009).

The division of cluster 12 provides four main groups (3-6, Figure 3). First, it separates eastern orosubmediterranean forests (groups 3 and 4) from samples from xerophilous suprasubmediterranean and supramediterranean forests (groups 5 and 6). Then, the following threshold discriminates between basiphilous (group 4) and silicicolous forests (group 3). The first principal component axis (PCA-1) separates samples from groups 3 and 4 with low positive values from those of groups 5 and 6 with negative values (Figure 4). Groups 3 and 4 represent easternmost Pinus sylvestris var. iberica forest communities from the Ayllón and Pela ranges respectively. They are placed together on PCA-1 because they have less $\mathrm{Tm}(\leq 0 \mathrm{C})$ and $\mathrm{TA}\left(<9^{\circ} \mathrm{C}\right)$ but also because their PA $(<700 \mathrm{~mm})$ and $\mathrm{Pm}(<83 \mathrm{~mm})$ values are lower; and along PCA-2 (positive values) by their low arboreal cover (3 or 4) (Figure 4, Table 1).

Group 3 (samples 38, 55 and 56) represents supramediterraneanm, suprasubmediterranean and orosubmediterranean subcontinental humid and hyperhumid Pinus sylvestris var. iberica mesoforests from the Ayllón Range growing between 1,520-1,800 $\mathrm{m}$ asl (Table 1) on siliceous soils (quartzites, slates and sandstones) in the oromediterranean belt of the Ayllón Range (Alto Rey Range, Figure 1). These forests were studied by De la Cruz \& Peinado (1996) without assigning any specific association, but pointing out their differences with western communities from the Guadarrama Range (Avenello ibericae-Pinetum ibericae) by the absence of Cytisus oromediterraneus and Juniperus communis subsp. alpina. Floristically they are characterized by Avenella iberica, Juniperus communis subsp. hemisphaerica, Cistus laurifolius, the relative abundance of Ericaceae (Arctostaphylos uva-ursi, Calluna vulgaris, Erica australis subsp. aragonensis, and E. arborea) and the virtual absence of broom species (Genisteae, ABAD-GARRIDO \& MARTínEZ-LABARGA, 2009). The pollen diagram (Figure 2) clearly indicates the importance of the above mentioned taxa (Cistus type 2-3\%, Calluna vul- garis 1.5-3\%, Juniperus 2-4\%, Erica arborea 2$8 \%$, E. australis 2-3\%, Arctostaphylos uva-ursi $2-5 \%$ ) and the sporadic percentages of Genisteae $(<0.5 \%)$. Samples from group 3 in the PCA plot (Figure 4) are arranged close to the relevant pollen indicator taxa (Figure 5) and therefore represent quite well the observed vegetation conditions quite well. According to these facts, we propose a new association for these forests: Erico aragonensis-Pinetum ibericae Sánchez-Mata, Gavilán \& López-Sáez ass. nova hoc loco (DE LA CRUZ \& PeInAdo 1996: 340, Table 1, holotypus rel. 1).

Group 4 (samples 57 and 58) represents semicontinental subhumid basiphilous relict mesoforests of the Ononido aragonensis-Pinetum ibericae from the oromediterranean belt of the Pela Range (Figure 1). The occurrence of these basiphilous forests can be recognized in the pollen diagram (Figure 2) by relatively high percentages of Ononis t. (3.3-5.6\%), Juniperus (6-10\%), Arctostaphylos uva-ursi (1-8\%) and Labiatae (2\%), although Pinus sylvestris/nigra (43-53\%) is the dominant pollen type in the dataset. Floristically they are rich in Ononidetea species and they are characterized by Juniperus communis subsp. hemisphaerica, Ononis aragonensis, Bupleurum gramineum, Vicia pyrenaica and Pulsatilla rubra (De LA CRUZ \& PEINADO, 1996; GAVILÁN \& al., 2012). Although these forests occupy low altitudes (1,370-1,445 $\mathrm{m}$ asl, Table 1$)$, the climatic parameters that characterize them, particularly their thermicity index (It 43.4-62.4), leads to define these forests as orophilous, occupying the lower oromediterranean belt (DE LA CRUZ \& PEINADO, 1996; MARTÍNEZ-GARCía \& MonTERO, 2000). Both samples 57 and 58 are arranged close to Ononis type and other above mentioned pollen taxa in the PCA plot (Figure 5).

Group 5 (samples 39 to 41) included pollen assemblages from xero-mesophilous Pinus sylvestris var. iberica forest communities (TA $\sim 10^{\circ} \mathrm{C}$, $\mathrm{Tm}>1{ }^{\circ} \mathrm{C}, \mathrm{PA} \sim 1000 \mathrm{~mm}$ ) from the northern Gredos Mountains developing at an altitudinal level ranging from 1465 to $1575 \mathrm{~m}$ (Figure 1, Table 1) on granite soils. These three samples are individualized in the same cluster (Figure 3), as well as in the PCA biplot (Figure 4), because they produce pollen assemblages with low values of Pinus 
sylvestris/nigra (53-56\%), Poaceae (10-17\%), Genisteae (1.5-3\%) and Juniperus $(<0.3 \%)$ major differences separating these samples from those of group 2 -, and average percentages of mesophilous taxa such as Pteridium (2.3\%), Veronica (1-2\%) and Prunus/Rubus (0-1\%). They are also characterized by the presence of the hemi-parasitic plant Viscum album (1-2\%), which currently only parasitizes Pinus sylvestris populations of the northern slopes of the Gredos Range (LóPEZ-SÁEZ, 1992, 1993; LóPEZ-SÁEZ \& SANZ DE BREMOND, 1992). Groups 5 and 6 are placed close in the cluster $1^{2}$ and the PCA-1 due to their palynological affinities (Figures 3 and 4), but they are individualized on the PCA-2 by high percentages of Pteridium in group 6 and the absence of Cistus type in group 5 (Figure 2). These two palynomorph taxa are positioned with negative values on PCA-2 (close to samples from group 6) while samples from group 5 show positive values on this axis (Figures 4 and 5).

Floristically, group 5 represents Pinus sylvestris var. iberica relict mesoforests from the supratemperate submediterranean and supramediterranean humid belt of the Gredos Mountains only present in the northern slopes of the Gredos Range in scattered nuclei (Navarredonda de Gredos, Hoyos del Espino). They are characterized by western endemic elements such as Festuca elegans subsp. merinoi, Centaurea amblensis, Ornithogalum concinnum and Genista cinerascens (MARTíneZ-García \& Montero, 2000; De la Fuente \& OrtúÑEZ, 2001), as well as dense broom communities mainly composed by Cytisus scoparius and Genista florida (GAVILÁN \& al., 2011). This fact allows us to propose a new pinewood association: Festuco merinoi-Pinetum ibericae Sánchez-Mata, Gavilán \& López-Sáez ass. nova hoc loco (Table 3, holotypus, rel. 5).

Finally, group 6 (samples 21 to 37) and group 7 (samples 42 to 54) represent xero-thermophilous and mesophilous Pinus sylvestris var. iberica forests respectively, from the Guadarrama Range, except sample 42 from the Gredos Range. Their pollen assemblages are characterized by noticeable percentages of Pinus sylvestris/nigra (55$81 \%)$, Cistus, Pteridium, Poaceae, and significant frequencies $(<5 \%)$ of Scrophulariaceae, Car- dueae, Erica arborea, Labiatae, Prunus/Rubus, Crataegus and Viscum album (Figure 2). The PCA axis 1 separates samples from group 6 (score 0 to -0.5 ) and group 7 (score -0.5 to -1 ) on the left part of the axis with negative values (Figure 4), in relation to altitude and climatic parameters (Table 1). Our results coincide with those obtained by Martínez-García \& Montero (2000). However, some overlap is detected on the PCA2 (Figure 4). Higher values of anthropogenic pollen taxa (Cichorioideae, Cardueae, Plantago lanceolata) and coprophilous fungi in samples from group 7 (Figure 2) indicates that pine forests at lower altitudes are subjected to greater human impact, especially livestock grazing (LÓPEZ-SÁEZ \& LÓPEZ-MERINO, 2007).

Groups 6 and 7 are individualized both in the HCA (clusters $1^{2}$ and 2) and PCA-1 (Figures 3 and 4) by the following features: (i) higher percentages of Pteridium (7.5-15.7\%), Rumex acetosella, Prunus/Rubus, Crataegus, Cichorioideae, Plantago lanceolata, Caryophyllaceae, Apiaceae and coprophilous fungi in mesophilous forests (group 7); (ii) higher values of xerophilous taxa such as Poaceae, Genisteae and Cistus in xerotermophilous pollen assemblages (group 6); and, (iii) the presence of Veronica only in group 7 and Lavandula stoechas in group 6. Sample 21 is included in group 6 although it is placed into a different cluster in the HCA, but in an intermediate position close to group 7. On PCA-1 this sample is also situated between groups 6 and 7. Its pollen assemblage is similar to those from group 6 but with high percentages of coprophilous fungi like samples from group 7 .

Groups 6 and 7 represent supratemperate submediterranean and supramediterranean subhumid and humid semicontinental Pinus sylvestris var. iberica mesoforests of the Pteridio aquilini-Pinetum ibericae association from the Guadarrama Range (Rivas-MartíneZ \& al., 2001, 2002). These forests have been probably extended by human activities and sometimes it is difficult to discriminate between natural and cultivated stands. Floristically, they are characterized by Avenella iberica, Conopodium pyrenaeum, Festuca braun-blanquetii, Galium rotundifolium, Juniperus communis subsp. hemisphaerica and 
Pteridium aquilinum. In the oromediterranean belt they are replaced by the Avenello ibericaePinetum ibericae microforests. Pollen types for taxa almost exclusively found in groups 6 and 7 , such as Pteridium, Prunus/Rubus, Cistus, Veronica and Lavandula stoechas have been found on the negative side of the first axis (Figures 4 and 5), and thus characterize samples from the Pteridio aquilini-Pinetum ibericae .

\section{CONCLUSIONS}

Recent years have seen a very controversial discussion among paleoecologists (CARRIÓN \& FERNÁNDEZ, 2009; CARRIÓN, 2010; LóPEZ-SÁEZ \& al.2010b) and phytosociologists (FARRIs \& al., 2010; LOIDI \& al., 2010; MuCINA, 2010; LOIDI \& FERNÁNDEZ-GONZÁLEZ, 2012) in reference to (i) different interpretations of the 'potential natural vegetation' (PNV) concept, and (ii) the conceptualization of vegetation dynamics from a historical perspective. This debate has even reached to other researchers concerning the possibilities of mapping PVN (CHIARUCCI \& al., 2010; LOIDI \& FERNÁNDEZGONZÁLEZ, 2012; SOMODI \& al., 2012).

It is not our goal to keep on feeding this absurd misunderstanding and the best evidence is the presented paper demonstrating precisely that both positions should not be so far away but the opposite: the convenience of a multidisciplinary and interdisciplinary approach to an integrated framework for the study of plant communities from a dynamic, temporal and spatial perspective.

It is true that for a long time phytosociological literature obviated Pinus sylvestris var. iberica forests from the Iberian Central System; in some cases they have been considered as vegetation complexes and framed within different geographical races (GALÁN DE MERA \& al., 1999); the remaining relict forests from the Gredos, Ayllón and Pela ranges, as well as those from the supramediterranean belt of the Guadarrama Range, have been assumed to be derived mainly from afforestation (RIVAS GODAY, 1956; RIVAS-MARTíNEZ, 1963, 1964, 1968, 1975, 1982, 1987; IZCO, 1984; RIVAS-MARTÍNEZ \& al., 1987a, 1987b, 1990; Peinado \& Martínez-Parras, 1985;
Rivas-Martínez \& Cantó, 1987; Monje-AReNAS, 1988; SÁNCHEZ-MATA, 1989; FERNÁNDEZGONZÁLEZ, 1991). However, in some cases it has been recognized the potential character of Pinus sylvestris var. iberica communities in the Gredos Range taking into account fossil pollen records (SÁNCHEZ-MATA, 1999). Rivas-Martínez \& MoLINA (1997, nom. inval. ICPN, art. 3; in RivasMartínez \& al., 1999) defined for the first time the silicicolous and climatophilous pinewood communities Avenello ibericae-Pinetum ibericae from the orotemperate submediterranean territory and Pteridio aquilini-Pinetum ibericae (Galio rotundifolii-Pinetum ibericae Rivas- Martínez \& Molina 1997, nom. inval. ICPN, art. 3; in RivasMartínez \& al., 2002) from the supramediterranean and supratemperate submediterranean of the Guadarrama Range, representing both the natural potential vegetation. DE LA CRUZ \& PEINADO (1996) proposed simultaneously the Galio idubedae-Pinetum sylvestris association for the basiphilous pinewoods from the Pela Range. Later studies have continued accepting them (PEINADO \& al., 2009), although the latter has been corrected as Ononido aragonensis-Pinetum ibericae (RIVAS-MARTíneZ \& al., 1999, 2001, 2002).

According to these new phytosociological proposals, modern pollen rain studies and multivariate analyses allow us to discriminate the peculiarities of Pinus sylvestris var. iberica forest communities from the Gredos Range and to propose two new phytosociological associations: Echinosparto barnadesii-Pinetum ibericae and Festuco merinoi-Pinetum ibericae.

In fact, fossil pollen data have revealed the existence of a continuous band of Scots pine forests on both orosubmediterranean and suprasubmediterranean areas (reaching some supramediterranean sites) of this range during at least the last seven thousand years. Pollen records from Puerto de la Peña Negra (1,909 m asl), Puerto de Chía (1,701 $\mathrm{m}$ asl), Puerto de Serranillos (1,700 m asl), Narrillos del Rebollar (1,560 m asl), Hoyos del Espino $(1,450 \mathrm{~m})$, Navarredonda de Gredos (1,550 m asl), Garganta de los Caballeros (1,365 m asl), Hoyocasero (1,250 m asl), Baterna (1,140 m asl), and Riatas $(1,120 \mathrm{~m}$ asl $)$ peat bogs provide clear evidence of these facts (FRANCO-MúGICA, 1995; 
ANDRADE \& al., 1996; FrANCO-MÚGICA \& al., 1997; DORADO \& al., 2001; ANDRADE \& GONZÁLEZ-JONTE, 2007; LÓPEZ-MERINO \& al., 2009; LÓPEZ-SÁEZ \& al., 2009a, 2009b; RUIZ-ZAPATA \& al., 2011).

The development of La Mesta system, the organization of high-mountain pastoral spaces with the use of montane areas as summer pasturelands, as well as the repeated use of fire, since $13^{\text {th }}$ century, but more particularly after its dissolution in 1836, were the main reasons of the abrupt disappearance of most Pinus sylvestris forests from the Gredos Range (LÓPEZ-SÁEZ \& al., 2009b), where only small groups are currently represented on the northern slope and scattered trees on both northern and southern slopes (GÉNOVA \& al., 1992; MARTÍNEZ-GARCÍA \& MONTERO, 2000). A similar picture is observed in other mountains such as Guadarrama and Ayllón ranges (FrANCO-MúGICA, 1995; FRANCO-MÚGICA \& al., 1998, 2001b; GÓMEZGONZÁLEZ \& al., 2009) although with much lesser intensity allowing the current existence of wide forests; and even in the Pela Range where pinewoods deforestation occurred since the Roman period (CURRÁs \& al., 2012). It is particularly noteworthy that the fossil pollen record also demonstrates the existence of Pinus sylvestris forests in western areas of the Iberian Central System where they have currently disappeared, such as the Béjar and Francia ranges for most of the Holocene (ATIENZA \& al., 1996; LÓPEZ-JIMÉNEZ \& LÓPEZ-SÁEZ, 2005; RUIZ-ZAPATA \& al., 2011; ABEL-SCHAAD, 2012; ABel-SchaAd \& LóPEZ-SÁEZ, 2013; MoralesMolino \& al., 2013).

\section{SYNTAXONOMICAL SCHEME}

JUNIPERO SABINAE-PINETEA SYLVESTRIS Rivas-Martínez 1965 nom. inv. propos.

Junipero sabinae-Pinetalia sylvestris Rivas-Martínez 1965 nom. inv. propos.

Junipero sabinae-Pinion ibericae Rivas Goday ex Rivas Goday \& Borja 1961 corr. Rivas-Martínez \& J.A. Molina in Rivas-Martínez, Fernández-González \& Loidi 1999

Ononido aragonensis-Pinetum ibericae (Rivas Goday \& Borja 1961) Rivas-Martínez 1969 corr. Rivas-Martínez, T.E. Díaz, Fernández-González, Izco, Loidi, Lousã \& Penas 2002

Avenello ibericae-Pinion ibericae Rivas-Martínez \& J.A. Molina in Rivas-Martínez, FernándezGonzález \& Loidi 1999

Avenello ibericae-Pinetum ibericae Rivas-Martínez \& J.A. Molina in Rivas-Martínez, Fernández-González \& Loidi 1999

Pteridio aquilini-Pinetum ibericae Rivas-Martínez \& J.A. Molina in Rivas-Martínez \& al. 2002 Echinosparto barnadesii-Pinetum ibericae Sánchez-Mata, Gavilán \& López-Sáez ass. nova

Festuco merinoi-Pinetum ibericae Sánchez-Mata, Gavilán \& López-Sáez ass. nova

Erico aragonensis-Pinetum ibericae Sánchez-Mata, Gavilán \& López-Sáez ass. nova

\section{FLORISTIC APPENDIX}

Avenella iberica (Rivas Mart., Izco \& Costa) Rivas Mart.

Cytisus striatus subsp. eriocarpus (Boiss. \& Reut.) Rivas Mart.

Erica australis subsp. aragonensis (Willk.) Cout.

Festuca braun-blaunquetii (Fuente, Ortúñez \& Ferrero) Rivas Mart., Fern. Gonz. \& Loidi

Festuca durandoi Clauson

Festuca elegans subsp. merinoi (Pau) Fuente et Ortúñez

Festuca gredensis Fuente \& Ortúñez

Jasione montana subsp. echinata (Boiss. \& Reut.) Rivas Mart.

Festuca paniculata subsp. multispiculata Rivas Ponce \& Cebolla

Leucanthemopsis pallida subsp. alpina (Boiss. \& Reut.) Rivas Mart., Fern. Gonz. \& Sánchez-Mata

Pinus sylvestris var. iberica Svoboda 


\section{REFERENCES}

Abad-Garrido, B. \& Martínez-Labarga, J.M. -2009- Caracterización ecológica de los pinares de pino silvestre en Castilla-La Mancha - In: S.E.C.G. Junta de Castilla y León (Eds.). $5^{\circ}$ Congreso Forestal Español. Montes y sociedad: Saber qué hacer. Pp. 2-12. Sociedad Española de Ciencias Forestales. Ávila.

Abel-Schaad, D. - 2012 - Evolución de la vegetación durante el Holoceno reciente en la vertiente extremeña del Sistema Central a partir del análisis palinológico $\mathrm{PhD}$ dissertation. Universidad de Extremadura. Plasencia.

Abel-Schaad, D. \& López-Sáez, J.A. - 2013 - Vegetation changes in relation to fire history and human activities at the Peña Negra mire (Béjar Range, Iberian Central Mountain System, Spain) during the past 4.000 years Veget. Hist. Archaeobot. 22: 199-214.

Andrade, A. \& González-Jonte, R.H. -2007- El pinar de Hoyocasero (Ávila) ¿antigua repoblación o pinar natural conservado? - An. Biol. 29: 33-51.

Andrade, A., Ruiz-Zapata, M.B., Gil-García, M.J. \& Fombella, M.A. - 1996- Acción antrópica y su impacto sobre la vegetación, desde el tránsito Subatlántico-Subboreal, en la vertiente norte de la Sierra de Gredos (Ávila, España). Estudio palinológico - In: Ruiz-Zapata, M.B. (Ed.). Estudios Palinológicos. Pp. 7-12. Universidad Alcalá de Henares. Alcalá de Henares,

Andrade, A., Valdeolmillos, A. \& Ruiz-Zapata, B. -1994Modern pollen spectra and contemporary vegetation in the Paramera mountain range (Avila, Spain) - Rev. Palaeobot. Palynol. 82: 129-139.

Atienza, M., Dorado, M., Gómez-Lobo, A. \& Ruiz-Zapata, M.B. - 1996- Estudio polínico de un depósito situado en la vertiente norte de la Sierra de Béjar - Bot. Macaron. 23: 201-209.

Austin, M.P. - 2013 - Inconsistencies between theory and methodology: a recurrent problem in ordination studies - J. Veg. Sci. 24: 251-268.

Barbero, M., Loisel, R., Quézel, P., Richardson, D.M. \& Romane, F. - 1998 - Pines of the Mediterranean basin In: Richardson, D.M. (Ed.). Ecology and biogeography of Pinus. Pp. 153-170. Cambridge Univ. Press. Cambridge.

Birks, H.J.B., Frey, D.G. \& Deevey, E.S. - 1998 - Numerical tools in palaeolimnology - progress, potentialities, and problems - J. Paleolimnol. 20: 307-332.

Bunting, M.J., Gaillard, M.J., Sugita, S., Middleton, R. \& Broström, A. -2004- Vegetation structure and pollen source area - Holocene 14: 651-660.

Cañellas-Boltà, N., Rull, V., Vigo, J. \& Mercadé, N. 2009- Modern pollen-vegetation relationships along an altitudinal transect in the central Pyrenees (southwestern Europe) - Holocene 19: 1185-1200.

Carrión, J.S. - 2010 - The concepts of potential natural vegetation (PNV) and other abstractions (trying to pick up fish with wet hands) - J. Biogeogr. 37: 2213-2215.
Carrión, J.S. \& Fernández, S. - 2009- The survival of the 'natural potential vegetation' concept (or the power of tradition - J. Biogeogr. 36: 2202-2203.

Carrión, J.S., Fernández, S., González-Sampériz, P., Gil-Romera, G., Badal, E., Carrión-Marco, Y., López-Merino, L., López-Sáez, J.A., Fierro, E. \& Burjachs, F. - 2010Expected trends and surprises in the Lateglacial and Holocene vegetation history of the Iberian Peninsula and Balearic Islands - Rev. Palaeobot. Palynol. 162: 458-475.

Caseldine, C., Fyfe, R., Langdon, C. \& Thomson, G. 2007 - Simulating the nature of vegetation communities at the opening of the Neolithic on Achill Island, Co. Mayo, Ireland- the potential role of models of pollen dispersal and deposition - Rev. Palaebot. Palynol. 144: 135-144.

Caseldine, C. \& Pardoe, H. - 1994- Surface pollen studies from alpine/sub-alpine southern Norway: applications to Holocene data - Rev. Palaeobot. Palynol. 82: 1-15.

Castroviejo, S. \& al. (Coord.) -1986-2010 - Flora iberica. Plantas vasculares de la Península Ibérica e Islas Baleares. Vols. I-VIII, X, XII-XV, XVII-XVIII, XXI - Real Jardín Botánico-CSIC. Madrid.

Chiarucci, A., Araújo, M.B., Decocq, G., Beierkuhnlein, C. \& Fernández-Palacios, J.M. - 2010 - The concept of potential natural vegetation: an epitaph? - J. Veg. Sci. 21: 1172-1178.

Court-Picon, M., Buttler, A. \& de Beaulieu, J.L. -2006Modern pollen/ vegetation/land-use relationships in mountain environments: an example from the Champsaur valley (French Alps) - Veget. Hist. Archaeobot. 15: 151-168.

Currás, A., Zamora, L., Reed, J.M., García-Soto, E., Ferrero, S., Armengol, X., Mezquita-Joanes, F., Marqués, M.A., Riera, S. \& Julià, R. -2012- Climate change and human impact in central Spain during Roman times: High-resolution multi-proxy analysis of a tufa lake record (Somolinos, $1280 \mathrm{~m}$ asl) - Catena 89: 31-53.

De la Cruz, M. \& Peinado Lorca, M. - 1996- El paisaje vegetal de la Cuenca del río Henares. I. Comunidades arbóreas y arbustivas - Wad-al-Hayara 23: 335-396.

De la Fuente, V. \& Ortúñez, E. - 2001- Festuca sect. Eskia (Poaceae) in the Iberian Peninsula - Folia Geobot. 36: 385-421.

Dorado, M. \& Ruiz-Zapata, B. -1994- Variabilidad de la lluvia polínica en los transectos TP1 y TP2 del Valle de Amblés (Ávila) - In: La Serna-Ramos, I. (Ed.). Polen y Esporas: Contribución a su conocimiento. Pp. 147-157. Universidad de La Laguna. Tenerife.

Dorado, M., Valdeolmillos, A. \& Ruiz-Zapata, M.B. 2001 - Actividad humana y dinámica de la vegetación en la Sierra de Ávila (Sistema Central Español) desde el Bronce Medio - Polen 11: 39-49.

Escudero,A., Gavilán, R. \& Rubio, A. - 1994- Una breve revisión de técnicas de análisis multivariantes aplicables en Fitosociología - Bot. Complutensis 19: 9-38. 
Faegri, K. \& Iversen, J. - 1989- Textbook of Pollen Analysis - Wiley. Chichester.

Farr, T.G., Rosen, P.A., Caro, E., Crippen, R., Duren, R., Hensley, S., Kobrick, M., Paller, M., Rodríguez, E., Roth, L., Seal, D., Shaffer, S., Shimada, J., Umland, J., Werner, M., Oskin, M., Burbank, D. \& Alsdorf, D. 2007- The Shuttle Radar Topography Mission - Rev. Geophys. 45: RG2004.

Farris, E., Filibeck, G., Marignani, M. \& Rosati, L. 2010 - The power of potential natural vegetation (and of spatial-temporal scale): a response to Carrión \& Fernández (2009) - J. Biogeogr. 37: 2211-2213.

Fernández-González, F. - 1991 - La vegetación del valle del Paular (Sierra de Guadarrama, Madrid), I — Lazaroa 12: 153-272.

Franco-Múgica, F. - 1995- Estudio palinológico de turberas holocenas en el Sistema Central: reconstrucción paisajística y acción antrópica - PhD dissertation. Universidad Autónoma. Madrid.

Franco-Múgica, F., García-Antón, M., Maldonado, J., Morla, C. \& Sainz-Ollero, H. - 2001a- The Holocene history of Pinus forests in the Spanish Northern Meseta - Holocene 11: 343-358.

Franco-Múgica, F., García-Antón, M., Maldonado, J., Morla, C. \& Sainz-Ollero, H. -2001b- Evolución de la vegetación en el sector septentrional del Macizo de Ayllón (Sistema Central). Análisis polínico de la turbera de Pelagallinas - Anales Jard. Bot.Madrid 59: 113-124.

Franco-Múgica, F., García-Antón, M. \& Sainz-Ollero, H. -1997 - Impacto antrópico y dinámica de la vegetación durante los últimos 2000 años BP en la vertiente septentrional de la Sierra de Gredos: Navarredonda (Ávila, España) - Rev. Paléobiol. 16: 29-45.

Franco-Múgica, F., García-Antón, M. \& Sainz-Ollero, H. -1998 - Vegetation dynamics and human impact in the Sierra de Guadarrama, Central System, Spain - Holocene 8: 69-82.

Gaillard, M.J., Birks, H.J.B., Emanuelsson, E. \& Berglund, B.E. - 1992 - Modern pollen/land-use relationships as an aid in the reconstruction of past land-uses and cultural landscapes: an example from south Sweden - Veget. Hist. Archaeobot. 1: 3-17.

Gaillard, M.J., Birks, H.J.B., Emanuelsson, E., Karlsson, S., Lagerås, L. \& Olausson, D. - 1994- Application of modern pollen-land-use relationships to the interpretation of pollen diagrams - reconstructions of land-use history in south Sweden, 3000-0 BP - Rev. Palaeobot. Palynol. 82: 47-73.

Galán de Mera, A., Hagen, Mª A. \& Vicente Orellana, J.A. 1999- Plant communities with Pinus sylvestris L. and Pinus nigra Arnold subsp. salzmannii (Dunal) Franco of the Spanish Sistema Central: a phytosociological approximation. Bot. Helv. 109: 21-54.

Gavilán, R. - 2005 - The use of climatic parameters and indices in vegetation distribution. A case study in the Spanish Sistema Central - Int. J. Biometeorol. 50: 111-120.

Gavilán, R., Fernández-González, F. \& Blasi, C. - 1998Climatic classification and ordination of the Spanish Sis- tema Central: relationships with potential vegetation Plant Ecol. 139: 1-11.

Gavilán, R.G., Vilches de la Serna, B. \& Fernández-González, F. - 2011 - Syntaxonomical review of Cytisetea scopario-striati communities in central Spain - Lazaroa 32: $29-72$

Gavilán, R.G., Díez-Monsalve, E., Izquierdo, J.L., Gutiérrez-Girón, A., Fernández-González, F. \& SánchezMata, D. - 2012- An approach towards the knowledge of Iberian high-mountain calcareous grasslands - Lazaroa 33: 43-50.

Génova, M.M., Gómez-Manzaneque, F. \& Regato, P. 1992 - Sobre los pinares relictos de la Sierra de Gredos (Ávila) - In: Actes del Simposi Internacional de Botànica "Pius Font i Quer"- Vol. II Fanerogàmia. Pp 439442. Institut d'Estudis Ilerdencs. Lleida.

Gil-Romera, G., López-Merino, L., Carrión, J.S., GonzálezSampériz, P., Martín-Puertas, C., López-Sáez, J.A., Fernández, S., García Antón, M. \& Stefanova, V. -2010Interpreting resilience through long-term ecology: potential insights in Western Mediterranean landscapes Open Ecol. J. 3: 43-53.

Gómez-González, C., Ruiz-Zapata, B., Gil-García, M.J., López-Sáez, J.A., Santiesteban, J., Mediavilla, R., Domínguez, F. \& Vera, S. - 2009- Evolución del paisaje vegetal durante los últimos 1.680 años BP en el Macizo de Peñalara (Sierra de Guadarrama, Madrid) - Rev. Esp. Micropal. 41: 75-89.

Grimm, E.C. - 1992 - Tilia version 2 - Illinois State $\mathrm{Mu}-$ seum. Research and Collection Center. Springfield.

Hicks, S. -2001 - The use of annual arboreal pollen deposition values for delimiting tree-lines in the landscape and exploring models of pollen dispersal - Rev. Palaebot. Palynol. 117: 1-29.

Izco, J. - 1984 - Madrid Verde - M.A.P.A. \& C.A.M. Madrid.

Jacobson, G.L. \& Bradshaw, R.H.W. - 1981 - The selection of sites for paleovegetational studies - Quat. Res. 16: 80-96.

Juggins, S. - 2007- User guide C2. Sofware for ecological and paleoecological data analysis and visualization. User guide Version 1.5 - University of Newcastle. Newcastle.

Loidi, J., Del Arco, M., Pérez de Paz, P.L., Asensi, A., Díez, B., Costa, M., Díaz, T., Fernández-González, F., Izco, J., Penas, A., Rivas-Martínez, S. \& Sánchez-Mata, D. 2010 - Understanding properly the 'potential natural vegetation' concept - J. Biogeogr. 37: 2209-2211.

Loidi, J. \& Fernández-González, F. -2012 - Potential natural vegetation: reburying or reboring? - J. Veg. Sci. 23: 596-604

López-Jiménez, O. \& López-Sáez, J.A. -2005 - Paleoambiente y formación de los paisajes antiguos de la comarca de la Sierra de Francia (Salamanca, España): de la estructura social a la creación del paisaje - Conimbriga 44: 5-24.

López-Leiva, C., Espinosa, J. \& Bengoa, J. -2009- Mapa de vegetación de Castilla y León. Síntesis 1:400.000 Junta de Castilla y León Valladolid. 
López-Merino, L., López-Sáez, J.A., Alba-Sánchez, F., Pérez-Díaz, S. \& Carrión, J.S. -2009- 2000 years of pastoralism and fire shaping high-altitude vegetation of Sierra de Gredos in central Spain - Rev. Palaeobot. Palynol. 158: 42-51.

López-Sáez, J.A. - 1992 - Contribución al estudio de las poblaciones de Viscum album L. subsp. austriacum (Wiesb.) Vollman en masas forestales de la provincia de Ávila - An. Biol. 18: 77-80.

López-Sáez, J.A. - 1993 - Contribución a la corología y ecología del muérdago (Viscum album L.) en el centro y norte de la Península Ibérica - Bol. San. Veg. Plagas 19: 551-558.

López-Sáez, J.A. - 1999 - Pollen morphology of Viscum spp. in Spain: its applications to Holocene Palaeoecology - Haustorium 34: 6.

López-Sáez, J.A., Alba-Sánchez, F., López-Merino, L. \& Pérez-Díaz, S. -2010a- Modern pollen analysis: a reliable tool for discriminating Quercus rotundifolia communities in Central Spain - Phytocoenologia 40: 57-72.

López-Sáez, J.A., Blanco, A., López-Merino, L., Ruiz-Zapata, M.B., Dorado, M., Pérez-Díaz, S., Valdeolmillos, A. \& Burjachs, F. - 2009a- Landscape and climatic changes during the end of the Late Prehistory in the Amblés Valley (Ávila, central Spain), from 1200 to $400 \mathrm{cal}$ BC - Quat. Int. 200: 90-101.30.

López-Sáez, J.A. \& López-García, P. - 1994- Contribution of the palaeoecological knowledge of Quaternary in the Tietar Valley (Sierra de Gredos, Ávila, Spain) Rev. Esp. Micropal. 26: 61-66.

López-Sáez, J.A. \& López-Merino, L. -2007- Coprophilous fungi as a source of information of anthropic activities during the Prehistory in the Amblés Valley (Ávila, Spain): the archaeopalynological record - Rev. Esp. Micropal. 39: 103-116.

López-Sáez, J.A., López-Merino, L., Alba-Sánchez, F. \& Pérez-Díaz, S. - 2009b-Contribución paleoambiental al estudio de la trashumancia en el sector abulense de la Sierra de Gredos - Hispania 69: 9-38.

López-Sáez, J.A., López-Merino, L., Alba-Sánchez, F., Pérez-Díaz, S., Abel-Schaad, D. \& Carrión, J.S. 2010b - Late Holocene ecological history of Pinus pinaster forests in the Sierra de Gredos of central Spain Plant Ecol. 206: 195-209.

López-Sáez, J.A. \& Sanz de Bremond, C. -1992- Viscum album L. y sus hospedantes en la Península Ibérica Bol. San. Veg. Plagas 18: 817-825.

Martínez-García, F. \& Montero, G. -2000- Typology of Pinus sylvestris L. forests in Spain - Invest. Agrar-Sist. Recursos Fores. Fuera de Serie 1: 41-65.

Mason, W.L. \& Alía, R. - 2000 - Current and future status of Scots pine (Pinus sylvestris L.) forests in Europe Invest. Agrar-Sist. Recursos Fores. Fuera de Serie 1: 317-335.

Monje-Arenas, L. - 1988 - La vegetación de Castilla-La Mancha: Ensayo de síntesis fitosociológica - Junta de Comunidades de Castilla-La Mancha. Toledo.
Moore, P.D., Webb, J.A. \& Collinson, M.E. - 1991 - Pollen analysis (2nd ed.) - Blackwell Scientific Publications. London.

Morales-Molino, C., García-Antón, M., Postigo, J.M., Morla, C. -2013 - Holocene vegetation, fire and climate interactions on the westernmost fringe of the Mediterranean Basin - Quat. Sci. Rev. 59: 5-17.

Mucina, L. - 2010 - Floristic-phytosociological approach, potential natural vegetation, and survival of prejudice Lazaroa 31: 173-182.

New, M., Lister, D., Hulme, M. \& Makin, I. -1999- A high-resolution data set of surface climate over global land areas - Clim. Res. 21: 1-25.

Ninyerola, M., Pons, X. \& Roure, J.M. -2006- Monthly precipitation mapping of the Iberian Peninsula using spatial interpolation tools implemented in a Geographic Information System - Theor. Appl. Climatol. 89: 195-209.

Ninyerola, M., Pons, X. \& Roure, J.M. -2007-Objective air temperature mapping for the Iberian Peninsula using spatial interpolation and GIS - Int. J. Climatol. 27: 1231-1242.

Pardoe, H.S. - 2001 - The representation of taxa in surface pollen spectra on alpine and sub-alpine glacier forelands in southern Norway - Rev. Palaeobot. Palynol. 117: 63-78.

Pausas, J.C., Llovet, J., Rodrigo, A. \& Vallejo, R. - 2008Are wildfires a disaster in the Mediterranean basin? A review - Int. J. Wild. Fire 17: 713-723.

Peinado Lorca, M. \& Martínez-Parras, J.M. -1985- El paisaje vegetal de Castilla-La Mancha - Junta de Comunidades de Castilla-La Mancha. Toledo.

Peinado Lorca, M., Monje-Arenas, L. \& Martínez-Parras, J.M. -2009- El paisaje vegetal de Castilla-La Mancha. Manual de Geobotánica - Ed. Cuarto Centenario, Albacete.

Pons, X. \& Ninyerola, M. -2007- Mapping a topographic global solar radiation model implemented in a GIS and refined with ground data - Int. J. Climatol. 28: 1821-1834.

Poska, A. \& Pidek, I.A. -2010 - Pollen dispersal and deposition characteristics of Abies alba, Fagus sylvatica and Pinus sylvestris, Roztocze region (SE Poland) Veg. Hist. Archaeobot. 19: 91-101.

Prados, A., Ubera, J.L. \& Domínguez, E. -1985 - Estudio palinológico de la tribu Genisteae R. BR. en Andalucía Occidental - Anal. Asoc. Pal. Lengua Esp. 2: 35-41.

Ramil, P., Aira, M.J. \& Saá, P. - 1992- Clave polínica de las Ericaceae gallegas - Lazaroa 13: 33-40.

Rehfeldt, G.E., Tchebakova, N.M., Parfenova, Y.I., Wykoff, W.R., Kuzmina, N.A. \& Milyutin, L.I. - 2002- Intraspecific responses to climate in Pinus sylvestris. - Glob. Change Biol. 8: 912-929.

Richardson, D.M., Rundel, P.W., Jackson, S.T., Teskey, R.O., Aronson, J., Bytnerowicz, A., Wingfield, M.J. \& Procheş, Ş. - 2007 - Human impacts in Pine Forests: Past, present, and future - Annu. Rev. Ecol. Evol. Syst. 38: 275-297.

Rivas-Goday, S. - 1956- Ubersicht über die Vegetationsgurtel der Iberischen Halbinsel kennezeichnende Arten und Gesellschaften - Veröff. Geobot. Inst. Rübel (Zurich) 31: 39-69. 
Rivas-Martínez, S. - 1964- Estudio de la vegetación y flora de las Sierras de Guadarrama y Gredos - An. Inst. Bot. Cavanilles 21(1): 5-325.

Rivas-Martínez, S. - 1965 - Esquema de la vegetación potencial y su correspondencia con los suelos en la España peninsular - An. Inst. Bot. Cavanilles 22: 341-405.

Rivas-Martínez, S. - 1968 - Los jarales de la Cordillera Central - Collect. Bot. 7: 1033-1082.

Rivas-Martínez, S. -1975- Mapa de vegetación de la provincia de Ávila - An. Inst. Bot. Cavanilles 32: 1493 1556.

Rivas-Martínez, S. -1982 - Memoria del Mapa de las Series de vegetación de la provincia de Madrid - Dip. Madrid, Madrid.

Rivas-Martínez, S. -1987- Memoria del MAPA de Series de Vegetación de España, escala 1:400.000 - M.A.P.A. \& I.C.O.N.A., Madrid.

Rivas-Martínez, S. -2005- Notions on dynamic-catenal phytosociology as a basic of landscape science - Plant Biosyst. 139: 135-144.

Rivas-Martínez, S. \& al. -2007- Mapa de series, geoseries y geopermaseries de vegetación de España [Memoria del mapa de la vegetación potencial de España], parte I - Itinera Geobot. 17: 5-436.

Rivas-Martínez, S. \& al. -2011a - Mapa de series, geoseries y geopermaseries de vegetación de España [Memoria del mapa de la vegetación potencial de España], parte II - Itinera Geobot. 18: 5-800.

Rivas-Martínez, S., Belmonte, D., Cantó, P., Fernández, F., Fuente, V., Moreno, J.M., Sánchez-Mata, D. \& Sancho, L.G. - 1987a - Piornales, enebrales y pinares oromediterráneos (Pino-Cytision oromediterranei) en el Sistema Central - Lazaroa 7: 93-124.

Rivas-Martínez, S. \& Cantó, P. - 1987 - Datos sobre la vegetación de las Sierras de Guadarrama y Malagón - Lazaroa 7: 235-257.

Rivas-Martínez, S., Cantó, P., Fernández-González, F., Molina, J.A., Pizarro, J.M. \& Sánchez-Mata, D. -1999Synopsis of the Sierra de Guadarrama vegetation - Itinera Geobot. 13: 189-206.

Rivas-Martínez, S., Díaz, T.E., Fernández-González, F., Izco, J., Loidi, J., Lousã, M. \& Penas, A. -2002 - Vascular plant communities of Spain and Portugal. Addenda to the Syntaxonomical checklist of 2001 - Itinera Geobot. 15: 5-922.

Rivas-Martínez, S., Fernández-González, F., Loidi, J., Lousã, M. \& Penas, A. -2001 - Syntaxonomical checklist of vascular plant communities of Spain and Portugal to association level - Itinera Geobot. 14: 5-341.

Rivas-Martínez, S., Fernández-González, F. \& SánchezMata, D. -1987b - El Sistema Central: de la Sierra de Ayllón a Serra da Estrela - In: Peinado Lorca, M. \& Rivas-Martínez, S. (Eds.). La vegetación de España. Pp. 419-451. Universidad de Alcalá de Henares. Madrid.
Rivas-Martínez, S., Fernández-González, F., Sánchez-Mata, D. \& Pizarro, J. - 1990 - Vegetación de la Sierra de Guadarrama - Itinera Geobot. 4: 3-132.

Rivas-Martínez, S. \& Molina, J.A. - 1997- Sintaxonomía de la alianza Junipero hemisphaericae-Pinion sylvestris Rivas-Martínez 1983 - In: Proceedings XVI Jornadas de Fitosociología. Pp. 63-64. Universidad de Almería. Almería.

Rivas-Martínez, S., Rivas Sáenz, S. \& Penas, A. -2011bWorldwide bioclimatic classification system. Global Geobotany 1: 1-634 + 4 maps.

Rubiales, J.M., García-Amorena, I., Génova, M., GómezManzaneque, F. \& Morla, C. -2007- The Holocene history of highland pine forests in a submediterranean mountain: the case of Gredos mountain Range (Iberian Central Range) - Quat. Sci. Rev. 26: 1759-1770.

Rubiales, J.M., Morales-Molino, C., García, S. \& GarcíaAntón, M. - 2012- Negative responses of highland pines to anthropogenic activities in inland Spain: a palaeoecological perspective - Veg. Hist. Archaeobot. 21: 397-412.

Ruiz de la Torre, J. -2002 - Mapa Forestal de España. Escala 1:200.000. Memoria general -Org. Aut. Parques Nacionales, Madrid.

Ruiz-Zapata, M.B., Carrasco, R.M., Gil-García, M.J., Pedraza, J., Razola, L., Domínguez-Villar, D. \& Gallardo, J.L. - 2011 - Dinámica de la vegetación durante el Holoceno en la Sierra de Gredos (Sistema Central Español) - Bol. R. Soc. Esp. Hist. Nat. Geol. 105: 109-123.

Sánchez-Mata, D. - 1989- Flora y vegetación del Macizo Oriental de la Sierra de Gredos (Ávila) - Inst. Gran Duque de Alba. Ávila.

Sánchez-Mata, D. - 1999- Bioclimatología: Una ciencia avanzada para la caracterización del medio natural In: Discursos de Entrada 1998. Pp. 95-112. Inst. Gran Duque de Alba. Ávila.

Somodi, I., Molnár, Z. \& Ewald, J. -2012 - Towards a more transparent use of the potential natural vegetation concept - an answer to Chiarucci et al. - J. Veg. Sci. 23: 590-595.

Sugita, S. - 1994 - Pollen representation of vegetation in Quaternary sediments: theory and method in patchy vegetation - J. Ecol. 82: 881-897.

Tapias, R., Climent, J., Pardos, J. \& Gil, L. -2004 - Life histories of Mediterranean pines - Plant Ecol. 171: 53-68.

Tutin, T.G., Heywood, V.H., Burges, N.A., Moore, D.M., Valentine, D.H., Walters, S.M. \& Webb, D.A. - 19641980 - Flora Europaea, 5 vols. - Cambridge Univ. Press, Cambridge.

Vázquez, R. \& Peinado Lorca, M. -1993- Relations between modern pollen rain and vegetation in the Sierra de Guadarrama (Madrid, Spain) - Ecol. Medit. 19: 59-76.

Ward, J.H. -1963 - Hierarchical grouping to optimize an objective function - J. Am. Stat. Assoc. 58: 236-244. 